\title{
PERILAKU NELAYAN DALAM PENGELOLAAN WISATA BAHARI DI KAWASAN PANTAI LOVINA, BULELENG, BALI
}

\author{
FISHERMEN BEHAVIOR IN MANAGING COASTAL TOURISM \\ IN LOVINA BEACH AT BULELENG, BALI
}

Siti Amanah dan Hamidah Nayati Utami

\begin{abstract}
Fishermen living around the Lovina Beach Tourism Area had other productive activities besides catching fishes. The fishermen living in coastal villages of Lovina offered services such as guides for tourists who were interested in diving, snorkeling, and watching dolphin's attraction in their habitat. The objectives of this research were to portray the fishermen's behavior in managing the tourism services and to determine the variables correlated to the fishermen behavior and the tourist satisfaction. The research showed that the fishermen's competencies in managing the tourism related activities need improvement, especially in the management of coastal resources and services. Furthermore, all of the fishermen'variables, whether internal or external, were positively and significantly correlated with their coastal tourism management behavior and the tourists satisfaction. It was recommended that along with the purposes of promoting tourism and the fishermen quality of life, learning programs that were developed based upon the fishermen's problems and needs were required. The programs could include hospitality training, eco-tourism, and tourism management. Additionally, coordination amongst the fishermen groups, local government, non government organization, and private sector involved in these activities was needed to improve the performance of the tourism service.
\end{abstract}

Key words: behavior, fishermen, eco-tourism.

\section{Pendahuluan}

Masyarakat pesisir khususnya nelayan sangat bergantung pada pemanfaatan pesisir dan laut. Salah satu upaya pemanfaatan potensi sumber daya pesisir dan laut adalah untuk jasa wisata bahari.

Terdapat tiga alasan utama yang mendukung kawasan pesisir menjadi lokasi wisata. Pertama, terdapat beragam ekosistem yang saling berkaitan di wilayah pesisir, seperti hutan mangrove, pantai berpasir, padang lamun, dan terumbu karang. Kedua, permintaan akan pariwisata pesisir mengalami peningkatan dari tahun ke tahun. Ketiga, di negara kepulauan seperti Indonesia, pariwisata pesisir merupakan andalan utama.
Kawasan Wisata Pantai Lovina di Kabupaten Buleleng, Bali dikembangkan sejak tahun 1970-an oleh Panji Tisna. Kata Lovina merupakan kependekan dari Love Indonesia, dan lokasi Pantai Lovina adalah 10 km di sebelah Barat Singaraja.

Kondisi lingkungan pesisir yang masih asri, tenang, dan indah, serta tersedianya sarana dan prasarana penunjang yang lengkap meliputi penginapan, rumah sakit, kantor pos, warung telekomunikasi, dan warung internet, membuat wilayah Lovina diminati wisatawan mancanegara terutama dari Eropa.

Beberapa jasa wisata di Pantai Lovina adalah wisata keindahan kawasan pesisir, scuba diving, melihat lumba-lumba (cruising) dan memancing. Nelayan ambil bagian dalam wisata bahari terutama penyewaan perahu. 
Profesionalitas nelayan dalam wisata bahari berkaitan dengan faktor internal maupun eksternal. Oleh karena itu tujuan penelitian ini adalah untuk:

(1) mengungkap perilaku nelayan dalam pengelolaan jasa wisata bahari;

(2) menjelaskan hubungan antara faktor internal (umur, pendidikan formal dan nonformal, pengalaman usaha di bidang pariwisata bahari, kekosmopolitan, kemampuan bahasa, motif usaha di bidang pariwisata bahari, modal usaha di bidang pariwisata bahari, dan sumber pendapatan utama) dan faktor eksternal (ketersediaan sarana dan prasarana pariwisata, karakteristik komoditas dan atraksi wisata, sumber informasi, nilai-nilai norma adat dan kebijakan pemerintah daerah) dengan perilaku nelayan dalam pengelolaan jasa wisata bahari di Pantai Lovina; dan

(3) menjelaskan hubungan dan pengaruh faktor internal dan eksternal terhadap kepuasan wisatawan dalam jasa wisata bahari.

\section{Tinjauan Umum tentang Perilaku, Nelayan, Pesisir, dan Wisata Bahari}

\section{Perilaku}

Perilaku merupakan pencerminanpencerminan yang ditampakkan oleh seseorang sebagai hasil interaksi dari sifatsifat genetis dan lingkungan (Padmowihardjo, 1978). Perilaku berkaitan dengan kemampuan fisik maupun non fisik dan umumnya unsurunsur perilaku dapat dikelompokkan menjadi tiga unsur yaitu pengetahuan (kognitif), keterampilan (psikomotor), dan sikap mental (afektif).

Kecakapan memahami sesuatu masalah, toleransi, kemampuan memper-timbangkan sesuatu, dan keterampilan menggerakkan otototot tubuh merupakan unsur perilaku. Perilaku dapat diamati oleh orang lain, dapat didengar, dilihat atau dirasakan oleh orang lain. Secara singkat, perilaku adalah keseluruhan tindakan seseorang yang dapat diamati oleh orang lain.
Kemampuan kerja seseorang sangat ditentukan oleh interaksi ketiga aspek perilaku di atas. Dengan demikian, dalam peningkatan kemampuan nelayan mengelola usaha jasa wisata bahari ketiga aspek perilaku tersebut dapat dikembangkan.

Upaya perubahan perilaku nelayan melalui proses pembelajaran, dapat ditempuh melalui langkah-langkah berikut (Hickerson dan J. Middleton, 1975; Padmowihardjo, 1999):

(1) Merencanakan aspek-aspek perilaku mana yang terutama akan dikembangkan dalam proses belajar mengajar.

(2) Mengatur lingkungan belajar yang memungkinkan bagi sasaran didik itu mencapai penambahan kemampuan secara berkesinambungan.

\section{Nelayan}

Nelayan merupakan orang yang secara aktif melakukan pekerjaan menangkap ikan/binatang air lainnya/tanaman air (Undang-Undang Nomor 31 Tahun 2004).

Nelayan dapat dibagi menjadi empat kategori yaitu nelayan tradisional yang bersifat subsisten, nelayan yang telah menggunakan teknologi penangkapan ikan yang maju, nelayan komersil, dan nelayan industri (Pollnac, 1998).

Nelayan memiliki kehidupan yang khas secara geografis, sosial, dan ekonomi (Hanson, 1984). Secara geografis, nelayan dihadapkan pada kondisi topografi yang khas, kondisi alam yang keras. Secara sosial, nelayan memiliki jaringan sosial yang guyub, terdapat berbagai pola stratifikasi, dan terkadang terjadi konflik.

Secara ekonomi, sering ditemui akumulasi modal pada sejumlah orang. Kesejahteraan nelayan sangat bervariasi antara satu daerah dengan yang lain, nelayan kecil umumnya dihadapkan pada berbagai keterbatasan, sehingga sulit mengakses berbagai layanan publik. 


\section{Pesisir}

Wilayah pesisir merupakan wilayah peralihan antara ekosistem laut dan daratan. Ada tiga pengertian tentang batas wilayah pesisir yaitu:

(1) secara ekologis: kawasan daratan yang masih dipengaruhi oleh proses-proses kelautan, seperti pasang surut; dan ke arah laut dipengaruhi oleh proses-proses daratan, seperti sedimentasi;

(2) secara administratif: batas terluar sebelah hulu dari kecamatan dan ke arah laut sejauh 12 mil dari garis pantai untuk provinsi; dan

(3) dalam perencanaan: bergantung pada permasalahan atau substansi yang menjadi fokus pengelolaan wilayah pesisir, misalnya: pencemaran dan sedimentasi: suatu kawasan darat di mana dampak pencemaran dan sedimentasi yang ditimbulkan memberikan dampak di kawasan pesisir. Jika membahas tentang pengelolaan hutan mangrove, maka yang disebut pesisir adalah: batas terluar bagian hulu kawasan mangrove.

Untuk kepentingan studi ini, wilayah pesisir didefinisikan sebagai wilayah peralihan antara laut dan daratan, kearah darat mencakup daerah yang masih terkena pengaruh percikan air laut atau pasang surut, dan ke arah laut meliputi daerah paparan benua (Beatley et al., 1994).

Wilayah pesisir memiliki karakteristik yang khas (Dahuri dkk, 2001), yang berbeda dengan wilayah daratan (terrestrial upland). Tiga ciri unik ekosistem pesisir yang membuat pengelolaannya lebih menantang (challenging) dibandingkan dengan pengelolaan pada ekosistem di darat maupun di laut lepas (high seas) adalah (a) Sistem lingkungan alam yang kompleks; (b) Pemanfaatan yang sangat beragam; dan (c) Kepemilikan.

Di wilayah pesisir dan lautan terdapat berbagai kegiatan pembangunan yang terbagi dalam berbagai sektor seperti konservasi, taman suaka alam laut, wisata, pelayaran, navigasi dan transportasi, perikanan, industri pertambangan, kegiatan mencemari lingkungan dan penelitian kelautan dan metereologi (Dahuri dkk, 2001).

Kegiatan pembangunan di kawasan pesisir tentunya tidak terlepas dari daya dukung lingkungan, keberlangsungan sumber daya alam dan dilakukan secara terpadu oleh berbagai pihak terkait dengan menekankan pada peningkatan kesejahteraan masyarakat setempat.

Sumberdaya perikanan dan kelautan sangat potensial dikembangkan untuk berbagai bidang kegiatan, mulai perikanan tangkap, budidaya laut, transportasi, pertambangan hingga pariwisata.

Pengembangan masing-masing sektor tentunya harus dilakukan secara bijak dan tidak saling tumpang tindih, diperlukan koordinasi antar stakeholders terkait pengelolaan pesisir dan lautan.

\section{Wisata Bahari}

Undang-Undang Nomor 9 Tahun 1990 memberikan batasan mengenai wisata, wisatawan, dan pariwisata, yaitu wisata adalah kegiatan perjalanan atau sebagian dari kegiatan tersebut yang dilakukan secara suka rela serta bersifat sementara untuk menikmati obyek dan daya tarik wisata.

Wisatawan adalah orang yang melakukan wisata. Pariwisata adalah segala sesuatu yang berhubungan dengan wisata termasuk perusahaan, obyek-obyek dan daya tarik wisata; kepariwisataan adalah segala sesuatu yang terkait dengan penyelenggaraan pariwisata.

Obyek dan daya tarik wisata adalah segala sesuatu yang menjadi sasaran wisata. Kawasan pariwisata adalah kawasan dengan luas tertentu yang sebagian disediakan untuk kebutuhan pariwisata.

Perkembangan pariwisata bergantung pada aspek suprastruktur dan infrastrukur. Aspek suprastruktur merupakan fasilitas 
penunjang untuk pengunjung seperti penginapan, restoran, kolam renang, dll. Aspek infrastruktur meliputi ketersediaan air bersih, pembuangan sampah dan sumber daya listrik, akses ke airport, jalan, pelabuhan, dll. Tanpa adanya kedua aspek tersebut, maka pariwisata akan menyebabkan dampak negatif.

Pengelola pariwisata perlu mempertimbangkan biaya dan manfaat kegiatan pariwisata pesisir, agar kegiatan yang dilakukan dapat memberikan nilai tambah bagi masyarakat dengan tetap memperhatikan konservasi lingkungan.

Fokus utama kebijakan pengembangan pariwisata bahari sebagaimana disebutkan oleh Kusumastanto (2002) adalah (1) meningkatkan ketersediaan prasarana dan sarana publik; (2) meningkatkan kualitas dan kapasitas sumberdaya manusia dalam mengelola pariwisata bahari; (3) mengembangkan sistem pendataan dan informasi yang lengkap, sehingga memudahkan wisatawan mendapatkan informasi dan akses cepat, mudah serta murah; (4) mengembangkan aktivitas ekonomi non-pariwisata seperti industri kerajinan, perikanan, restoran, dan jasa angkutan laut; (5) meningkatkan jaminan dan sistem keamanan bagi wisatawan; (6) menciptakan iklim investasi yang kondusif bagi kalangan investor; (7) mengembangkan model pengelolaan pariwisata bahari yang mampu menjaga kelestarian ekosistem laut dan budaya masyarakat lokal.

Pariwisata di wilayah pesisir dapat dikembangkan dengan memperhatikan aspek konservasi, yaitu merupakan ecotourism: tidak merusak sumberdaya mengacu pada lingkungan, pendidikan, pemahaman berbagai pihak, dan harus memberikan manfaat jangka panjang di segala aspek, dan menjaga Marine Protected Areas.

Hal ini dilakukan melalui empat kegiatan terpadu harus dilakukan: (i) preservasi habitat penting, (ii) melindungi spesies yang terancam punah, (iii) mitigasi perusakan lingkungan yang kumulatif, dan (iv) menentukan level pada penggunaan sumber daya dapat pulih secara berkelanjutan.

\section{$\underline{\text { Metode Penelitian }}$}

Penelitian ini dilakukan di Kawasan Pantai Lovina, Buleleng, Bali mulai Maret hingga Oktober 2005. Penelitian ini merupakan penelitian deksriptif korelasional yaitu meneliti hubungan antar variabel dianalisis dengan uji statistik. Pendekatan kualitatif digunakan untuk menjelaskan substansi hasil uji stitistik.

Metode survai menggunakan teknik wawancara, pengamatan langsung, dan diskusi dengan pakar dan praktisi di lapangan. Responden nelayan yang diwawancarai berjumlah 30 orang, selain itu data didapat pula dari informan yaitu Staf Dinas Pariwisata Kab. Buleleng, Staf Dinas Perikanan dan Kelautan Kab. Buleleng, Ketua Kelompok Nelayan, dan pemuka masyarakat setempat. Data dianalisis secara kualitatif dan kuantitatif.

Peubah-peubah dalam penelitian ini adalah variabel karakteristik individu nelayan $\left(\mathrm{X}_{1}\right)$ dengan indikator: (1) Usia, (2) Pendidikan formal dan non formal, (3) Pengalaman usaha di bidang pariwisata, (4) Tingkat kosmopolitan, (5) Kemampuan bahasa, (6) Motif usaha di bidang pariwisata, (7) Modal usaha di bidang pariwisata, dan (8) Sumber pendapatan utama.

Variabel karakteristik lingkungan fisik dan sosial $\left(\mathrm{X}_{2}\right)$ meliputi: (1) Ketersediaan sarana dan prasarana pariwisata, (2) Karakteristik komoditas dan atraksi wisata, (3) Sumber informasi, (4) Nilai-nilai budaya lokal dan norma adat, (5) Peraturan (awigawig).

Variabel perilaku nelayan mengelola jasa wisata bahari $\left(\mathrm{Y}_{1}\right)$ menggunakan indikator: (1) Aspek pengetahuan/wawasan atau kognitif nelayan akan wisata bahari, (2) Aspek sikap mental/afektif dalam menjalankan peran sebagai pemandu wisata, (3) Aspek keterampilan/psikomotorik nelayan memandu wisatawan menggunakan perahu katil. 
Variabel kepuasan wisatawan $\left(\mathrm{Y}_{2}\right)$ Menggunakan indikator: (1) Terpenuhinya kebutuhan untuk kenyamanan, (2) Terpenuhinya kebutuhan untuk menikmati keindahan alam, dan (3) Terpenuhinya kebutuhan akan layanan prima dalam akomodasi, kunjungan, dan layanan hospitality.

\section{$\underline{\text { Hasil dan Pembahasan }}$}

Jenis-jenis layanan wisata yang ditawarkan oleh nelayan di Pantai Lovina adalah mengamati perilaku lumba-lumba, diving, dan snorkeling. Nelayan menyewakan perahu pada wisatawan untuk mengamati perilaku lumba-lumba mulai pukul 06.00 hingga pukul 09.00 pagi dengan sewa perahu berkisar antara $\mathrm{Rp} 40$ ribu hingga $\mathrm{Rp} 50$ ribu per trip.

Selama perjalanan dengan perahu, nelayan menjelaskan perilaku lumba-lumba dengan Bahasa Indonesia atau Inggris sesuai permintaan wisatawan. Istri nelayan biasanya melakukan aktivitas berdagang sambil menunggu nelayan tiba dari laut untuk menangkap ikan maupun memandu wisatawan. Dagangan istri nelayan berupa ikan segar, cindera mata, makanan dan minuman ringan.

Hasil penelitian menunjukkan bahwa usia rata-rata nelayan yang melakukan jasa wisata bahari adalah 42,5 tahun. Nelayan yang menyewakan perahu paling muda berusia 28 tahun, dan paling tua berusia 60 tahun. Pendidikan nelayan umumnya Sekolah Dasar dan SMP tidak tamat. Pengalaman nelayan dalam penyediaan jasa wisata bahari berkisar antara 5 hingga 26 tahun dengan rataan pengalaman adalah 14 tahun. Nelayan terlibat dalam pengelolaan wisata bahari didorong oleh upaya peningkatan pendapatan, dan merupakan pengaman ketika hasil penangkapan ikan rendah.

Sebagian besar nelayan di pantai Lovina memiliki pengetahuan tentang pengelolaan usaha wisata bahari, pengelolaan keuangan, pengetahuan dasar pemasaran jasa wisata bahari, dan pemahaman tentang cara melayani wisatawan dalam kategori sedang.

Sikap nelayan terhadap kedatangan wisatawan, sarana wisata baru, dan persaingan usaha dalam kategori sedang. Ketertarikan terhadap jenis pelayanan wisata bahari yang baru juga dalam kategori sedang. Keuletan mengelola usaha dan kelincahan memasarkan jasa wisata dalam kategori sedang, dan kecermatan memberikan pelayanan kepada wisatawan.

Kecermatan dalam pengelolaan keuangan masih rendah. Secara keseluruhan kreativitas nelayan mengelola kegiatan wisata bahari dan pengelolaan resiko usaha dalam kategori sedang. Akan tetapi, daya saing nelayan masih rendah.

Tingkat kepuasan wisatawan berdasarkan tingkat pemenuhan kebutuhan untuk leisure (kenyamanan) dalam kategori sedang (rataan skor=2,06), tingkat pemenuhan kebutuhan untuk menikmati keindahan pantai dalam kategori sedang (rataan skor= 2,1). Sedang pemenuhan harapan wisatawan dalam kategori sedang dengan nilai rataan skor yang lebih rendah yaitu 2,00.

Berdasarkan hasil uji korelasi Rank Spearman terbukti bahwa seluruh variabel memiliki hubungan positif yang nyata dengan nilai korelasi berkisar antara 0,762 hingga 0,912 (Tabel 1). Dengan demikian semakin baik kondisi internal dan eksternal nelayan, maka akan semakin menunjang kemampuan mengelola usaha wisata bahari. Pada gilirannya, perilaku pengelolaan jasa wisata bahari yang profesional akan dapat meningkatkan kepuasan wisatawan pengguna jasa tersebut. wisatawanpun menikmati layanan jasa wisata bahari.

Hasil analisis Chi-Square memperlihatkan bahwa seluruh indikator variabel internal dan eksternal nelayan memiliki hubungan yang nyata dengan perilaku nelayan mengelola jasa wisata bahari. Hasil analisis regresi memperlihatkan bahwa faktor internal, eksternal, dan perilaku berkontribusi positif terhadap kepuasan 
Tabel 1. Nilai Koefisien Korelasi Rank-Spearman Hubungan antara Variabel Internal dan Eksternal Nelayan dengan Perilaku Nelayan Mengelola Jasa Wisata Bahari

\begin{tabular}{llccc}
\hline \multicolumn{1}{c}{ Uraian } & \multicolumn{1}{c}{$\begin{array}{c}\text { Faktor } \\
\text { internal } \\
\text { nelayan }\left(\mathrm{X}_{1}\right)\end{array}$} & $\begin{array}{c}\text { Faktor } \\
\text { eksternal } \\
\text { nelayan }\left(\mathrm{X}_{2}\right)\end{array}$ & $\begin{array}{c}\text { Perilaku nelayan } \\
\text { mengelola jasa wisata } \\
\text { bahari }\left(\mathrm{Y}_{1}\right)\end{array}$ & $\begin{array}{c}\text { Kepuasan } \\
\text { wisatawan } \\
\left(\mathrm{Y}_{2}\right)\end{array}$ \\
\hline Faktor internal nelayan $\left(\mathrm{X}_{1}\right)$ & 1,000 & $0,810 * *$ & $0,762 * *$ & $0,823 * *$ \\
\hline Faktor eksternal nelayan $\left(\mathrm{X}_{2}\right)$ & $0,810 * *$ & 1,000 & $0,912 * *$ & $0,877 * *$ \\
\hline $\begin{array}{l}\text { Perilaku nelayan mengelola } \\
\text { jasa wisata bahari }\left(\mathrm{Y}_{1}\right)\end{array}$ & $0,762 * *$ & $0,912 * *$ & 1,000 & $0,835 * *$ \\
\hline Kepuasan wisatawan $\left(\mathrm{Y}_{2}\right)$ & $0,823 * *$ & $0,877 * *$ & $0,835 * *$ & 1,000 \\
\hline
\end{tabular}

Keterangan: ** nyata pada $\alpha=0,01 ; \mathrm{N}=30$

Peningkatan kompetensi nelayan dalam mengelola wisata bahari secara profesional dapat dilakukan dengan menggunakan pendekatan sistem. Sebuah sistem terdiri atas tiga komponen sub sistem sebagaimana dikemukakan oleh Haslett (2000) yaitu sub sistem masukan (input), proses (process), dan luaran (output). Komponen masukan terdiri atas sumber daya manusia, sumber daya alam, sarana dan prasarana pendukung (Gambar 1). Pengembangan kepariwisataan menuntut adanya potensi daerah wisata yang memiliki karakteristik yang khas.
Untuk mengembangkan pengelolaan usaha wisata bahari, diperlukan koordinasi antar lembaga dalam penanganan wisata diperlukan untuk menghindari konflik antar pemanfaat wilayah pesisir. Adanya berbagai pihak yang melakukan aktivitas di kawasan pesisir tanpa disertai konservasi dan pemulihan akan berdampak terhadap menurunnya kondisi lingkungan. Konservasi sumber daya alam tetap merupakan isu utama dalam pengelolaan wisata bahari di kawasan pesisir. Terlebih karang-karang di Lovina cukup indah, sehingga perlu dijaga kelestariannya.

\section{Gambar 1. Analisis Sistem Pengelolaan Wisata Bahari oleh Nelayan}

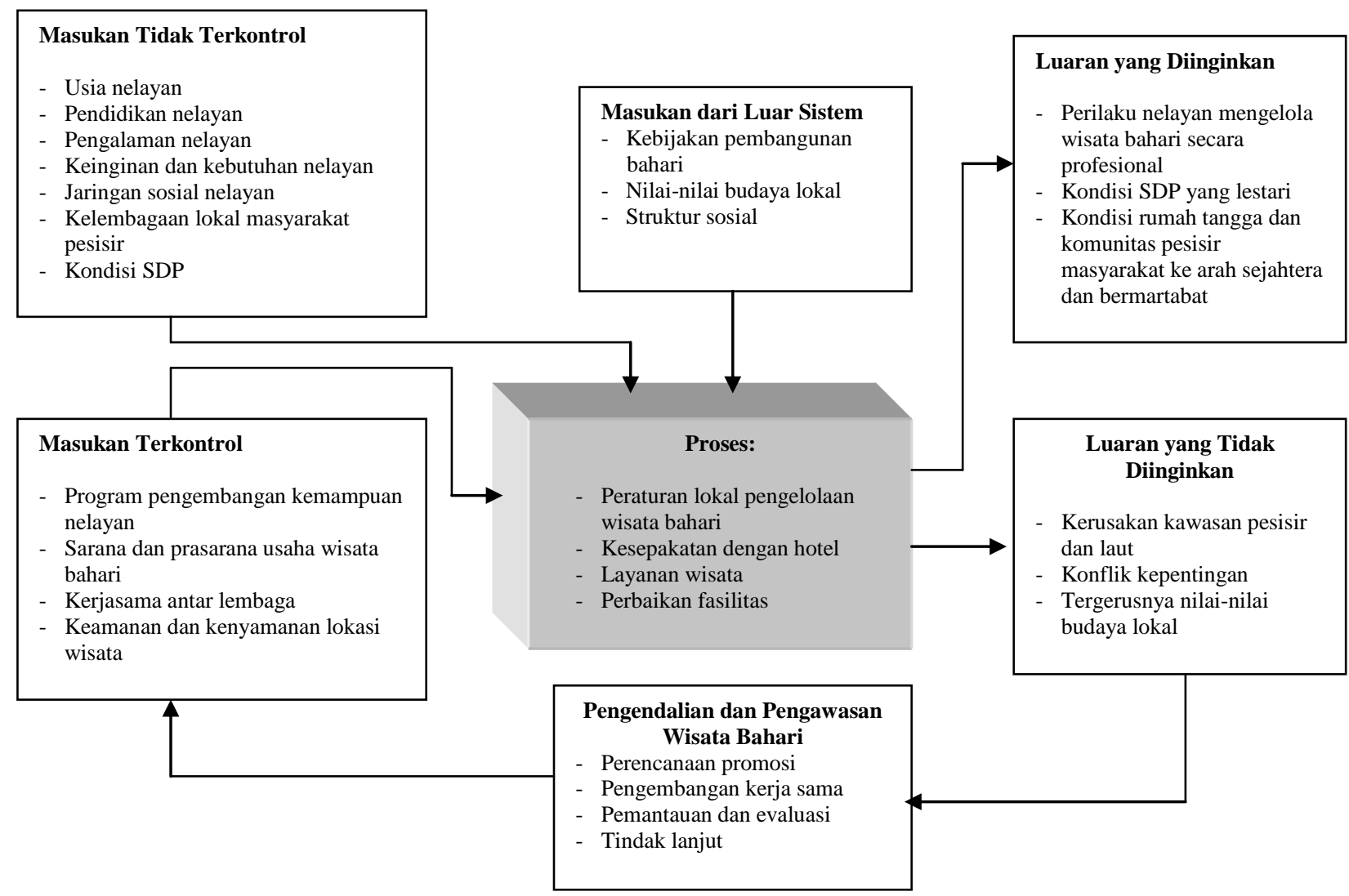


Secara sederhana, terdapat tiga komponen utama dalam mengelola wisata bahari di kawasan pesisir yaitu nelayan, sumberdaya pesisir, dan pengelolaan wisata bahari (Gambar 2).

Nelayan sebagai manusia memiliki perilaku, dalam hal ini perilaku merupakan resultan antara faktor pribadi dan lingkungan. Hasil penelitian ini membuktikan bahwa terdapat hubungan nyata antara faktor tersebut.

Peran fasilitator sangat diperlukan meningkatkan kemampuan nelayan baik tentang wawasan pelayanan jasa lingkungan yang memenuhi standar internasional, maupun yang berkaitan dengan empati dan keterampilan motorik di bidang wisata kebaharian.
Mengenai kawasan pesisir, perlu disadari kawasan memiliki sumber daya alam dapat pulih dan tidak dapat pulih. Implikasinya, perlu dilakukan rehabilitasi sumber daya dapat pulih seperti terumbu karang, padang lamun, maupun mangrove.

Khusus, untuk sumber daya yang tidak dapat pulih, maka perlu dilakukan pencegahan agar dampak lingkungan wisata bahari tidak merusak sumber daya tersebut.

Penerapan peraturan lokal seperti awig-awig untuk pengelolaan lingkungan dapat ditingkatkan efektivitasnya, sehingga kerusakan sumber daya pesisir yang tidak dapat pulih berupa abrasi, polusi udara, air dan tanah dapat dicegah.

Manajemen jasa lingkungan dapat dilakukan secara sinergis antara pemerintah, swasta, dan masyarakat nelayan.

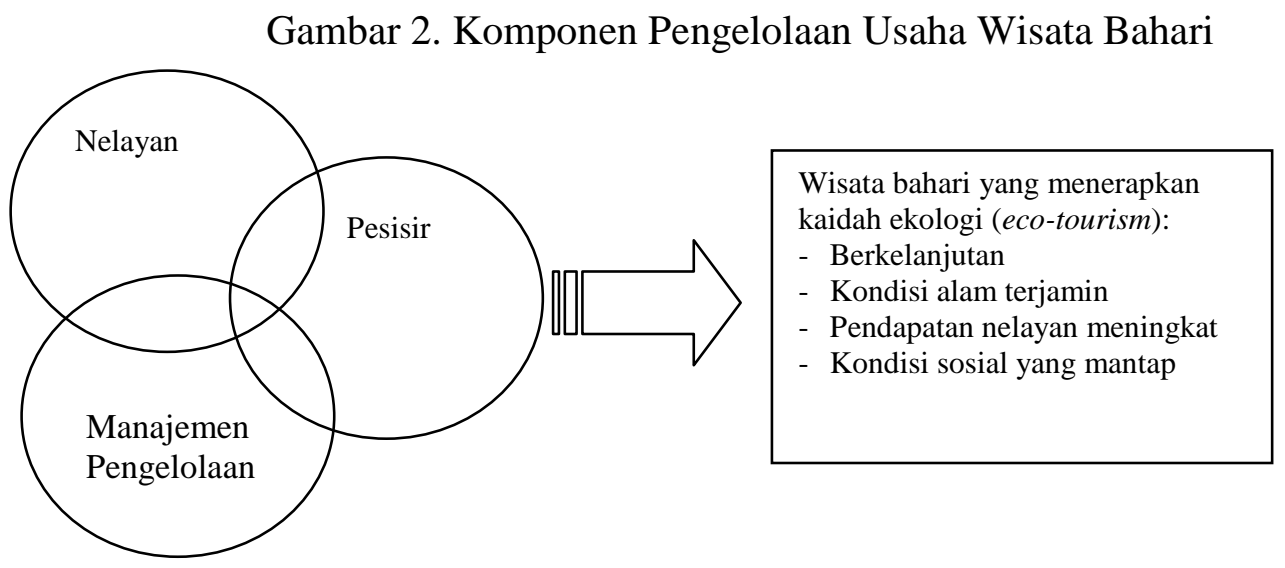

Dengan ditingkatkannya keterpaduan tiga unsur utama dalam pengelolaan jasa wisata bahari, diharapkan eco-tourism di kawasan Pantai Lovina dapat diwujudkan.

Dalam jangka panjang, penerapan ecocoastal and marine tourism dapat menjamin keberlanjutan sumber daya alam, pendapatan nelayan yang meningkat, dan dapat dicapainya kondisi sosial budaya yang mantap.
Wisata bahari yang menerapkan

ekologi (eco-tourism)

Pendapatan nelayan meningka

Kondisi sosial yang mantap

\section{$\underline{\text { Kesimpulan }}$}

(1) Nelayan mengelola wisata bahari secara subsisten, dan belum berorientasi pada kepuasan pelanggan. Profesionalitas pengelolaan jasa wisata bahari masih rendah.

(2) Seluruh indikator variabel internal dan eksternal nelayan memiliki hubungan yang nyata dengan perilaku nelayan mengelola jasa wisata bahari. Faktor 
internal, eksternal, dan perilaku nelayan yang profesional berkontribusi positif terhadap kepuasan wisatawan.

(3) Pengelolaan wisata bahari ditentukan oleh tiga unsur yaitu: manusia, kondisi pesisir dan manajemen wisata bahari. Sinergi ketiga unsur tersebut secara seimbang dapat menjamin keberlanjutan sumber daya alam dan kesejahteraan nelayan.

\section{Rujukan}

Beatley, T., D.J. Brower dan A.K. Schwab. 1994. An Introduction to Coastal Zone Management. Washington, DC: Island Press.

Dahuri, R. , Rais, J., Ginting, S.P., dan Sitepu, M.J. 2001. Pengelolaan Sumber Daya Wilayah Pesisir dan Lautan Secara Terpadu. Jakarta: PT. Pradnya Paramita.

Hanson, A. J. 1984. "Coastal Community: International Perspectives." Paper Presented at the 26 th Annual Meeting of the Canadian Commission for UNESCO. $\quad 6^{\text {th }}$ June 1984. Newfoundland: St John.

Haslett, Simon K. 2000. Coastal Systems. London: Routledge.
Hickerson, F.J. dan Middleton,J. 1975. Helping People Learn: A Module for Training Trainers. Honolulu, Hawaii: East-west Center, East-West Communication Institute.

Kusumastanto, T. 2002. Reposisi "Ocean Policy“ dalam Pembangunan Ekonomi Indonesia di Era Otonomi Daerah. [Orasi Ilmiah Guru Besar IPB]. Bogor: PKSPL dan PSPLT IPB.

Padmowihardjo, S. 1978. Beberapa Konsepsi Proses Belajar dan Implikasinya. Ciawi, Bogor: Institut Pendidikan, Latihan dan Penyuluhan Pertanian.

Padmowihardjo, S. 1999. Psikologi Belajar Mengajar. Jakarta: Universitas Terbuka.

Pollnac, R. B. 1988. "Karakteristik Sosial dan Budaya dalam Pembangunan Perikanan Berskala Kecil." Dalam M. Cernea, Mengutamakan Manusia dalam Perubahan: Variabel-variabel Sosiologi dalam Pembangunan Pedesaan. Jakarta: UI Press. 